\title{
Next generation sequencing in synovial sarcoma reveals novel gene mutations
} \author{
Groenen $^{2}$, Bastiaan B.J. Tops ${ }^{2}$, Eveline J. Kamping ${ }^{3}$, Rolph Pfundt ${ }^{3}$, Diederik R.H. \\ de Bruijn ${ }^{3}$, Ad H.M. Geurts van Kessel ${ }^{3}$, Han J.H.J.M. van Krieken², Winette T.A. \\ van der Graaf ${ }^{1,4}$ and Yvonne M.H. Versleijen-Jonkers ${ }^{1}$ \\ ${ }^{1}$ Department of Medical Oncology, Radboud University Medical Center, Nijmegen, The Netherlands \\ 2 Department of Pathology, Radboud University Medical Center, Nijmegen, The Netherlands \\ ${ }^{3}$ Department of Human Genetics, Radboud University Medical Center, Nijmegen, The Netherlands \\ ${ }^{4}$ The Institute of Cancer Research and The Royal Marsden NHS Foundation Trust, London, UK \\ Correspondence to: Myrella Vlenterie, email: myrella.vlenterie@radboudumc.nl \\ Keywords: next generation sequencing, KRAS, CCND1, synovial sarcoma, chromosomal aberrations \\ Received: June 21,2015 Accepted: August 31, $2015 \quad$ Published: September 22, 2015
}

Myrella Vlenterie $^{1}$, Melissa H.S. Hillebrandt-Roeffen ${ }^{1}$, Uta E. Flucke ${ }^{2}$, Patricia J.T.A.

This is an open-access article distributed under the terms of the Creative Commons Attribution License, which permits unrestricted use, distribution, and reproduction in any medium, provided the original author and source are credited.

\section{ABSTRACT}

Over $95 \%$ of all synovial sarcomas (SS) share a unique translocation, $t(X ; 18)$, however, they show heterogeneous clinical behavior. We analyzed multiple SS to reveal additional genetic alterations besides the translocation. Twenty-six SS from 22 patients were sequenced for 409 cancer-related genes using the Comprehensive Cancer Panel (Life Technologies, USA) on an Ion Torrent platform. The detected variants were verified by Sanger sequencing and compared to matched normal DNAs. Copy number variation was assessed in six tumors using the Oncoscan array (Affymetrix, USA). In total, eight somatic mutations were detected in eight samples. These mutations have not been reported previously in SS. Two of these, in KRAS and CCND1, represent known oncogenic mutations in other malignancies. Additional mutations were detected in RNF213, SEPT9, KDR, CSMD3, MLH1 and ERBB4. DNA alterations occurred more often in adult tumors. A distinctive loss of $6 q$ was found in a metastatic lesion progressing under pazopanib, but not in the responding lesion. Our results emphasize $t(X ; 18)$ as a single initiating event in SS and as the main oncogenic driver. Our results also show the occurrence of additional genetic events, mutations or chromosomal aberrations, occurring more frequently in SS with an onset in adults.

\section{INTRODUCTION}

Synovial sarcoma (SS) accounts for approximately $8 \%$ of all soft tissue sarcomas. Synovial sarcomas occur at all ages and sites throughout the body, with a predilection for the extremities of young adults. Patients with a synovial sarcoma have a 5-year cancer-specific survival rate of $66 \%$, with a remarkable better outcome for children as compared to adults [1]. Tumors can be aggressive, leading to early metastases and recurrences, or can be more indolent occurring as a long existing swelling that may recur years after the initial diagnosis [2]. Predicting tumor behavior has been attempted by relating survival to various tumor and patient characteristics.
Several of these characteristics have been proven to be of negative prognostic value, including large tumor size, primary tumor location in non-extremities and older age at diagnosis. The mechanism(s) underlying the differences in tumor behavior, however, remain to be resolved [Vlenterie, et al. Abstract 022 presented at CTOS 2014]. The treatment of localized disease involves surgery often supplemented with (neo)adjuvant radiotherapy and, occasionally, with (neo)adjuvant chemotherapy or a combination of both. Metastatic disease is treated by palliative chemotherapy or by applying the angiogenesis inhibitor pazopanib, with limited survival benefit [3].

Genetic profiling is believed to be the way forward to explore tumor behavior and to discover new therapeutic 
targets. Currently, genetic screening is being implicated in standard clinical practice for several cancers, including melanomas, lung and colon cancers. Interestingly, similar mutations are shared by different cancer types, and within one cancer type different genetic subtypes can be found, explaining its biologic behavior and/or therapy response. In addition, differences in mutations have been observed between primary tumors and their metastases, thereby providing insight in tumor evolution and therapy resistance $[4,5]$. Importantly, these insights have led to the development of new targeted therapies based on the use of monoclonal antibodies and tyrosine kinase inhibitors.

Sarcomas have also been subject to genetic screening, which has led to diagnostic implementation in several subtypes [6], including gene amplifications in well-differentiated and dedifferentiated liposarcomas [7] or distinct chromosomal translocations in, among others, myxoid liposarcomas [8]. Additionally, the discovery and treatment of the targetable alterations in hot spot regions in the KIT or PDGFRA genes in gastrointestinal stromal tumors (GIST) has significantly improved overall survival of these patients $[9,10]$.

A unique reciprocal translocation between chromosome X and 18 in over $95 \%$ of SS tumors was already reported in 1994, leading to fusions between one of the SSX genes (1,2 or 4) and the SS18 (SYT) gene $[11,12]$. This translocation is not found in any other human neoplasm. It has been shown that the SSX and SS18 (fusion) proteins participate in the SWI/SNF and Polycomb complexes, respectively, known to be involved in epigenetic gene (de)regulation [13, 14]. As knockdown of the fusion protein leads to cell death in vitro and in vivo and introduction of the translocation in mice forms histologically alike tumors [15] [16] [17], the translocation is believed to act as the central oncogenic driver in SS [18]. Next to its significance as a diagnostic marker, the clinical targeting of this translocation has so far remained elusive $[19,20]$. Also the putative predictive value of SS translocation subtypes has stayed unclear [21, 22].

Besides the X;18 translocation, additional genomic alterations have been reported in SS. First, patients with Li-Fraumeni syndrome (loss of p53 function) or neurofibromatosis (altered function of $N F 1$ gene) have a higher risk for SS [23]. Secondly, Sanger sequencing of synovial sarcomas has revealed mutations in several cancer-related genes, including TP53, TERT, CDH1, CTNBB1, APC, HRAS, PTEN, PI3KCA, EGFR, BCL9, SETD2, TRRAP and PDGFRA (Table 1). The targeted sequencing of other cancer-related genes, including KRAS [24], BRAF [24, 25], CDKN1A [26], KIT [27] (abstract only), JAK2, FOXL2, IDH1, AKT1 and EZH2 [25] did not reveal any pathogenic mutations. Since the percentages of affected tumors differ widely in comparable studies its reproducibility may be questioned, and in most studies (10 of 15) the detected variations were not verified in the corresponding normal DNAs. Joseph et al. performed whole-exome sequencing of a small cohort of SS ( $n$ $=7$ ), resulting in a relatively low mutation call [28]. Besides several mutations of unknown function, driver mutations in TP53 and SETD2 were found in one sample each. Thirdly, in addition to these nucleotide alterations, gross chromosomal aberrations have been detected by comparative genomic hybridization (CGH) [29-31], providing further insight into its genomic complexity next to the recurrent $\mathrm{X} ; 18$ translocation. A recent array $\mathrm{CGH}(\mathrm{aCGH})$ and gene expression profiling study by Przybyl et al. in a subset of SS revealed up-regulation of the AURKA and KIF18A genes in aggressive untreated primary tumors and its corresponding metastases or local recurrences, compared to untreated primary tumors from patients who did not develop metastases/local recurrences [32]. Finally, the study of Lagarde et al. showed that there is a correlation between genomic complexity, based on the number and type of chromosomal aberrations, and metastasis-free survival. Their study also showed a relation to age at diagnosis, with a larger instability being more frequent in adults than children [33]. This observation could explain why children show better survival rates than adults.

Here we used next generation sequencing in a relatively large SS cohort to assess the occurrence of genomic alterations, including mutations and gross chromosomal changes.

\section{RESULTS}

We included patients of all ages (range 11-78 years; including 8 children ( $<18$ years) and 19 adults ( $\geq 1$ yyears)) and both sexes (female: 15, male: 22). Patients were diagnosed between 1990 and 2014. Follow-up data was available for $32(86 \%)$ patients. For the screening of somatic mutations by means of next generation sequencing, we included 26 tumors from 22 patients (cohort 1) of whom sufficient tissue with matched normal tissue was available in the local tissue bank from our hospital pathology database. We included tumors with both histology and translocation subtypes (Table 2). The tumors encompassed 18 primary tumors, 6 metastatic tumors and 2 recurrences. Seventy-seven \% $(n=20)$ of the tumor samples were from chemotherapy naïve patients, three tumor samples were from patients treated with neo-adjuvant chemotherapy, one couple consisting of two metastatic lesions were derived from one patient treated with pazopanib, and one recurrence was from a localization previously treated with adjuvant radiotherapy. Of four patients paired lesions were available: three patients with a metastasis and the corresponding primary tumor, and one patient, as mentioned above, with two metastases that responded differently to pazopanib.

The 26 tumors were sequenced using the Comprehensive Cancer Panel, containing 409 cancerrelated genes including all previous found mutated 
Table 1: Previously reported non-synonymous mutations in synovial sarcoma.

\begin{tabular}{|c|c|c|c|c|c|}
\hline Gene & Examined part & Frequency & Sample size & Somatic & Reference \\
\hline \multirow[t]{4}{*}{ TP53 } & Exon 2-11 & 0 & 5 & $\mathrm{~N} / \mathrm{A}$ & [47] \\
\hline & Exon 5-9 & $6(12 \%)$ & 49 & Not validated & [48] \\
\hline & Unknown & 1 & 1 & Yes & {$[49]^{*}$} \\
\hline & Exon 5-8 & $2(6 \%)$ & 34 & Not validated & [50] \\
\hline$T E R T$ & $\mathrm{C} 250 \mathrm{~T}+\mathrm{C} 228 \mathrm{~T}$ & 1 & $25+5 \mathrm{CL}$ & Not validated & [51] \\
\hline \multirow[t]{2}{*}{ EGFR } & Exon 18-21 & $1(8 \%)$ & 12 & Not validated & [52] \\
\hline & Exon 18-21 & $1(\mathbf{5 0 \%})$ & 2 & Yes & [53] \\
\hline \multirow[t]{3}{*}{$C D H 1$} & Exon 4-9 & $12(24 \%)$ & 49 & Yes & [54] \\
\hline & Exon 4-9 & $5(12.5 \%)$ & 40 & Not validated & {$[55]$} \\
\hline & Unknown & $1(6 \%)$ & 16 & Not validated & [56] \\
\hline \multirow[t]{4}{*}{$C T N N B 1$} & Exon 3 & $4(8 \%)$ & 49 & Not validated & [57] \\
\hline & Exon 3 & 0 & 15 & $\mathrm{~N} / \mathrm{A}$ & [58] \\
\hline & Unknown & $2(12.5 \%)$ & 16 & Not validated & [56] \\
\hline & Exon 3 & $1(20 \%)$ & $5 \mathrm{CL}$ & Not validated & [37] \\
\hline \multirow[t]{3}{*}{$A P C$} & Exon 15 & $4(8 \%)$ & 49 & Yes & [59] \\
\hline & Unknown & 0 & 16 & $\mathrm{~N} / \mathrm{A}$ & [56] \\
\hline & Coding region & 0 & $5 \mathrm{CL}$ & $\mathrm{N} / \mathrm{A}$ & [37] \\
\hline$H R A S$ & Codon 12 and 13 & $3(6 \%)$ & 49 & Not validated & [48] \\
\hline \multirow[t]{2}{*}{ PTEN } & Exon 5-9 & $2(7 \%)$ & 30 & Not validated & {$[24]$} \\
\hline & Unknown & $7(14 \%)$ & 49 & Unknown & {$[60]^{*}$} \\
\hline \multirow[t]{3}{*}{$P I 3 K C A$} & Exon 9 and 20 & $2(7 \%)$ & 30 & Not validated & [24] \\
\hline & Exon $1,9,20$ & 0 & 23 & $\mathrm{~N} / \mathrm{A}$ & [61] \\
\hline & Exon 9, 20 & 0 & 8 & $\mathrm{~N} / \mathrm{A}$ & [25] \\
\hline \multirow[t]{2}{*}{ PDGFRA } & Exon $12 \& 18$ & $1(\mathbf{8 \%})$ & 12 & Not validated & [27] \\
\hline & Exon $12-16$ \& 18-21 & 0 & $25+2 \mathrm{CL}$ & $\mathrm{N} / \mathrm{A}$ & [38] \\
\hline Exome & $\begin{array}{l}\text { mutation in SETD2, } \\
\text { TP53, TRRAP, } \\
\text { BCL9 and other } \\
\text { mutations in non } \\
\text { cancer related genes }\end{array}$ & $1(14 \%)$ & 7 & Yes & {$[28]$} \\
\hline
\end{tabular}

A: RNF213

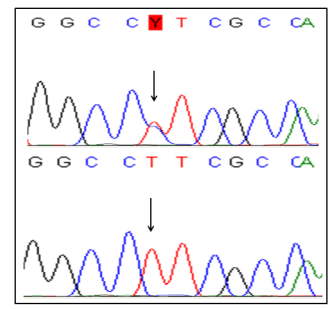

$\mathrm{E}: K D R$

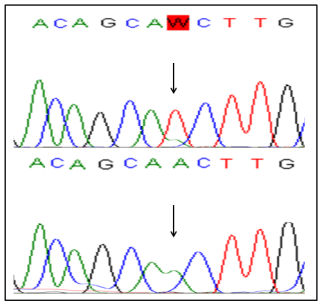

B: CCND1

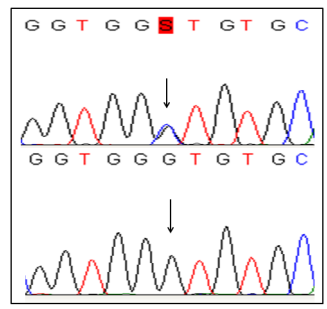

F: CSMD3

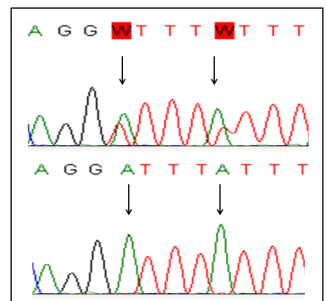

C: SEPTO9

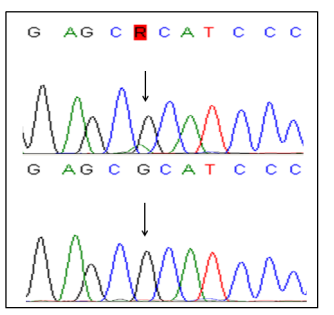

$\mathrm{G}: \mathrm{MLH} 1$

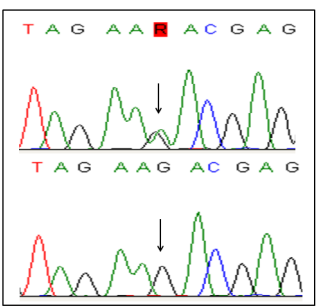

$\mathrm{D}: K R A S$

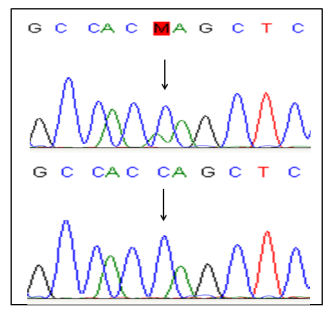

Figure 1: Sanger verification. Figure 1 shows the 8 verified mutations by Sanger sequencing in tumor tissue (top) with the corresponding normal tissue (bottom). 
Table 2: Patient characteristics.

\begin{tabular}{|c|c|c|c|}
\hline 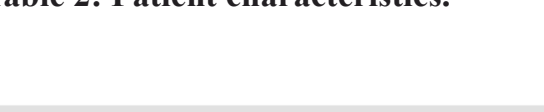 & $\begin{array}{r}\text { Cohort } 1 \\
(n=22) \\
\end{array}$ & $\begin{array}{r}\text { Cohort } 2 \\
(n=15) \\
\end{array}$ & $\begin{array}{r}\text { Patients with } \\
\text { a mutation }\end{array}$ \\
\hline $\begin{array}{ll}\text { Age } & \\
\text { - } & \text { Children ( }<18 \text { years) } \\
\text { - } & \text { Adult }(\geq 18 \text { years })\end{array}$ & $\begin{array}{r}6(27.3 \%) \\
16(72.7 \%)\end{array}$ & $\begin{array}{r}2(13.3 \%) \\
13(86.7 \%)\end{array}$ & $\begin{array}{r}1(12.5 \%) \\
7(24.1 \%) \\
(p=N S)\end{array}$ \\
\hline $\begin{aligned} \text { Sex } & \\
- & \text { Male } \\
- & \text { Female }\end{aligned}$ & $\begin{array}{r}16(72.7 \%) \\
6(27.3 \%)\end{array}$ & $\begin{array}{l}6(40 \%) \\
9(60 \%)\end{array}$ & $\begin{array}{r}6(27.3 \%) \\
2(13.3 \%) \\
(p=N S)\end{array}$ \\
\hline $\begin{array}{l}\text { Tumor localization } \\
\text { - Extremity } \\
\text { - Non-extremity } \\
\text { - Unknown }\end{array}$ & $\begin{array}{r}12(54.5 \%) \\
9(40.9 \%) \\
1(4.5 \%)\end{array}$ & $\begin{array}{r}9(40 \%) \\
6(60 \%) \\
0\end{array}$ & $\begin{array}{r}4(19.0 \%) \\
4(26.7 \%) \\
0 \\
(p=N S)\end{array}$ \\
\hline $\begin{array}{l}\text { Histology } \\
\text { - Monophasic } \\
\text { - Biphasic } \\
\text { - Unknown }\end{array}$ & $\begin{array}{l}11(50 \%) \\
8(36.4 \%) \\
3(13.6 \%)\end{array}$ & $\begin{array}{r}10(66.7 \%) \\
3(20 \%) \\
2(13.3 \%)\end{array}$ & $\begin{array}{r}4(19.0 \%) \\
3(27.3 \%) \\
1(20.0 \%) \\
(p=N S)\end{array}$ \\
\hline $\begin{array}{c}\text { Translocation } \\
\text { - SSX1 } \\
\text { - SSX2 }\end{array}$ & $\begin{array}{r}14(63.6 \%) \\
8(36.4 \%)\end{array}$ & $\begin{array}{r}11(73.3 \%) \\
4(26.7 \%)\end{array}$ & $\begin{array}{r}6(24.0 \%) \\
2(16.7 \%) \\
(p=N S)\end{array}$ \\
\hline $\begin{array}{l}\text { Follow up } \\
\quad \text { - } 5 \text { year overall survival } \\
\text { VS }=\text { not sionificant }(n>0.05)\end{array}$ & $62 \%$ & $67 \%$ & $\begin{array}{r}29.2 \% \\
(p=0.026)\end{array}$ \\
\hline
\end{tabular}
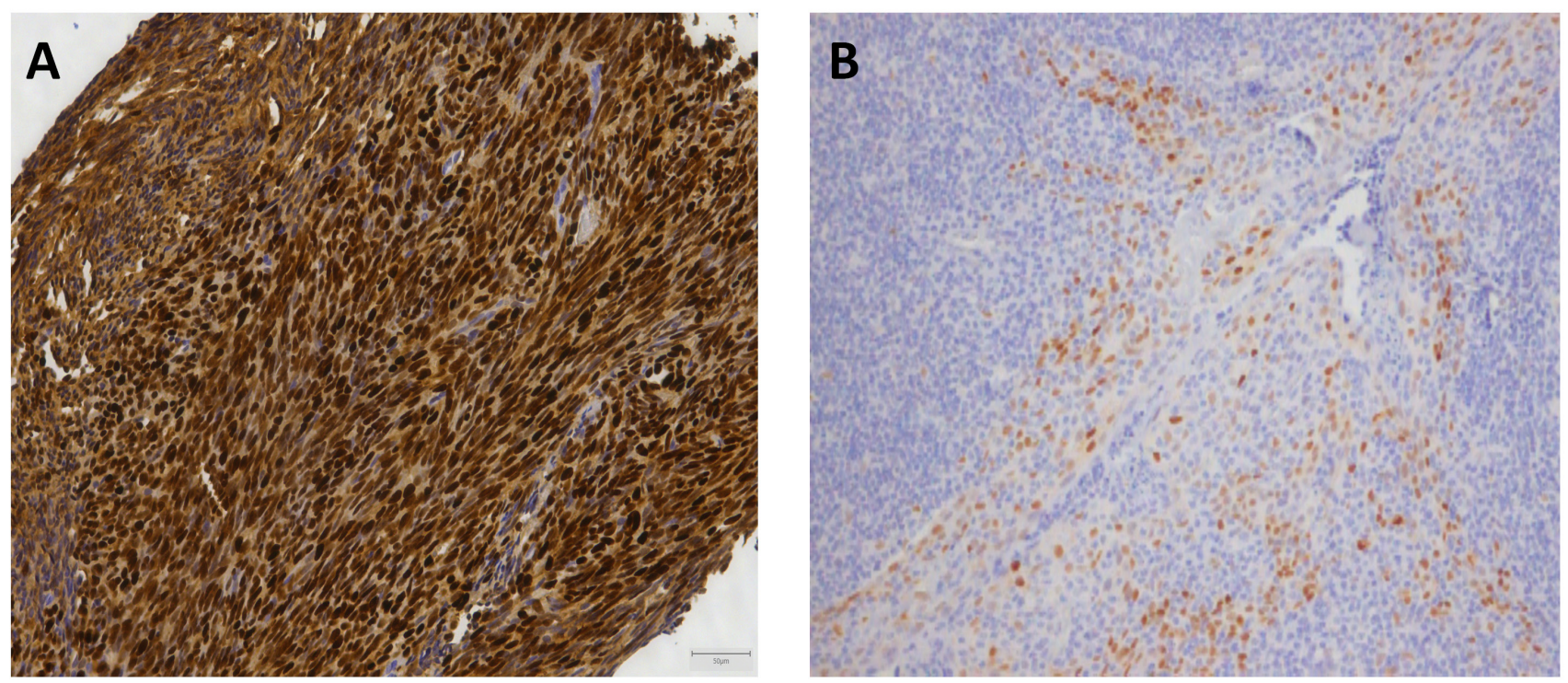

Figure 2: Immunohistochemistry of cyclin D1. Figure 2A shows the abundant overexpression of cyclin D1 by immunohistochemical staining. $2 \mathrm{~B}$ is the positive control (tonsil). Photos are made with 20x enlargement. 
Table 3: Sanger verified mutations

\begin{tabular}{|c|c|c|c|c|c|c|c|c|}
\hline $\mathbf{N r}$ & Gene & & Chr & Exon & $\begin{array}{c}\text { HG19 } \\
\text { notation }\end{array}$ & mRNA & $\begin{array}{l}\text { Amino } \\
\text { acid }\end{array}$ & Type \\
\hline $1 \mathrm{~A}$ & $R N F 213$ & $\begin{array}{l}\text { Ring } \\
\text { finger } \\
\text { protein } \\
213\end{array}$ & 17 & 29 & 78319549 & c. $7414 \mathrm{~T}>\mathrm{C}$ & p.F2472L & Missense \\
\hline 1B & $C C N D 1$ & Cyclin D1 & 11 & 5 & 69466021 & c. $859 C>G$ & p.P287A & Missense \\
\hline $1 \mathrm{C}$ & SEPTOO & Septin-9 & 17 & 5 & 75483596 & c. $1004 \mathrm{G}>\mathrm{A}$ & p.R335H & Missense \\
\hline 1D & $K R A S$ & $\begin{array}{l}\text { V-Ki-ras2 } \\
\text { Kirsten } \\
\text { rat } \\
\text { sarcoma } \\
\text { viral } \\
\text { oncogene } \\
\text { homolog }\end{array}$ & 12 & 2 & 25398285 & c. $34 \mathrm{C}>\mathrm{A}$ & p.G12C & Missense \\
\hline $1 E$ & $\begin{array}{l}K D R \\
\text { (a.k.a. } \\
V E G F R 2 \text { ) }\end{array}$ & $\begin{array}{l}\text { Kinase } \\
\text { insert } \\
\text { domain } \\
\text { receptor }\end{array}$ & 4 & 18 & 55963862 & c. $2581 \mathrm{~T}>\mathrm{A}$ & p.T861S & Missense \\
\hline $1 \mathrm{~F}$ & CSMD3 & $\begin{array}{l}\text { CUB and } \\
\text { Sushi } \\
\text { multiple } \\
\text { domains } 3\end{array}$ & 8 & 2 & 114327017 & $\begin{array}{c}\text { c. } 184 \mathrm{TAAAT} \\
>\text { AAAAA }\end{array}$ & p.IF62FF & Missense \\
\hline $1 G$ & MLHI & $\begin{array}{l}\text { MutL } \\
\text { homolog } \\
1\end{array}$ & 3 & 12 & 37067195 & c. $1106 \mathrm{C}>\mathrm{T}$ & p.S369F & Missense \\
\hline $1 \mathrm{H}$ & $\begin{array}{l}E R B B 4 \\
\text { (a.k.a. } \\
\text { HER4) }\end{array}$ & $\begin{array}{l}\text { Receptor } \\
\text { tyrosine- } \\
\text { protein } \\
\text { kinase } \\
\text { erbB-4 }\end{array}$ & 2 & 25 & 212285269 & c. $3032 \mathrm{~T}>\mathrm{A}$ & p.E2V & Missense \\
\hline
\end{tabular}

genes in SS, except for TERT and CDKN1A. In total 77,995 variants were called in the 26 tumors (range 755

- 5713). 96 single nucleotide variants remained after filtering. These remaining variants were verified by Sanger sequencing. Of these, 57 variants (59\%) could be confirmed. All were compared to matched normal DNA. In total, 49 of the 57 variants were also detected in normal DNA and were, thus, considered to be polymorphisms. Eight variants were not found in the normal tissues and are therefore assigned as somatic mutations (Table 3). These mutations were identified in the genes: $K R A S, C C N D 1$, RNF213, SEPT9, KDR (VEGFR2), CSMD3, MLH1 and $E R B B 4$ (HER4) (Figure 1). Seven of these mutations were found in primary tumor samples derived from therapy naïve patients. The KRAS mutation was found in a tumor sample from a patient who was treated with neo-adjuvant chemotherapy. The mutations in the oncogenes KRAS and $C C N D 1$ genes are well-established oncogenic mutations in other cancer types. The sample harboring the CCNDI mutation was further evaluated by immunohistochemistry, showing abundant over-expression of the protein (Figure
2). The sample harboring the $M L H 1$ mutation was also evaluated by immunohistochemistry for MLH1, MSH2, MSH6 or PMS2 expression in accordance to the effect of MLH1 in Lynch [34]. However, no lack of expression of any of these proteins was found (data not shown) in the tumor sample with the $M L H 1$ mutation.

No additional mutations were found in the metastatic lesions compared to the primary tumor. Since all mutations were found only once, we extended our cohort with a second cohort (Cohort 2, total $n=15$ ), one primary tumor sample was derived from a patient who was treated with neo-adjuvant chemotherapy, the rest were primary tumor samples from therapy naïve patients, to test whether the identified mutations might occur recurrently. In addition, we extended the sequencing with coding exons 1-5 of the CCND1 gene and coding exons 2-5 of the $K R A S$ gene, as the mutations that we found in these genes are proven pathogenic and, therefore, these two genes were considered to be of particular interest. However, no additional mutations were found in cohort 2 which means that after analysis of 41 tumors with these platforms, at 
maximum one mutation was found in each tumor, and no similar mutations were observed.

In addition to the above mutation screen, we also used the primary dataset of cohort 1 to search for the presence of copy number variations (CNVs). To this end, we compared the aligned number of reads per gene generated by NGS in tumor tissue with the aligned number of reads per gene in healthy tissue. By doing so, chromosomal aberrations, like partial loss of chromosome 3 or gain of chromosome 8 , were detected in approximately half of the SS. We confirmed these results in 6 samples with genome wide CNV analysis using the Oncoscan FFPE assay from Affimetrix (Figure $3 \mathrm{~A})$. Interestingly, differences in copy number alterations were seen in 2 of the 4 paired tumor lesions (Figure 3B) with additional deletions, duplications and loss of earlier duplications between the primary tumor and its corresponding metastasis. A specific loss of $6 q$ was found in the metastatic lesion which progressed under pazopanib treatment in contrast to the responding metastatic lesion. An additional (partial) deletion of chromosome $6 \mathrm{q}$ was found in 2 other tumors of cohort 1. Another recurrent finding was loss of heterozygosity $(\mathrm{LOH})$ in 5 of the 6 tumor samples at 3q13.33. Overall, tumors with chromosomal aberrations were more frequently seen in adults $(34.5 \%)$ compared to children $(12.5 \%)$, however this was not significant $(p=0.07)$.
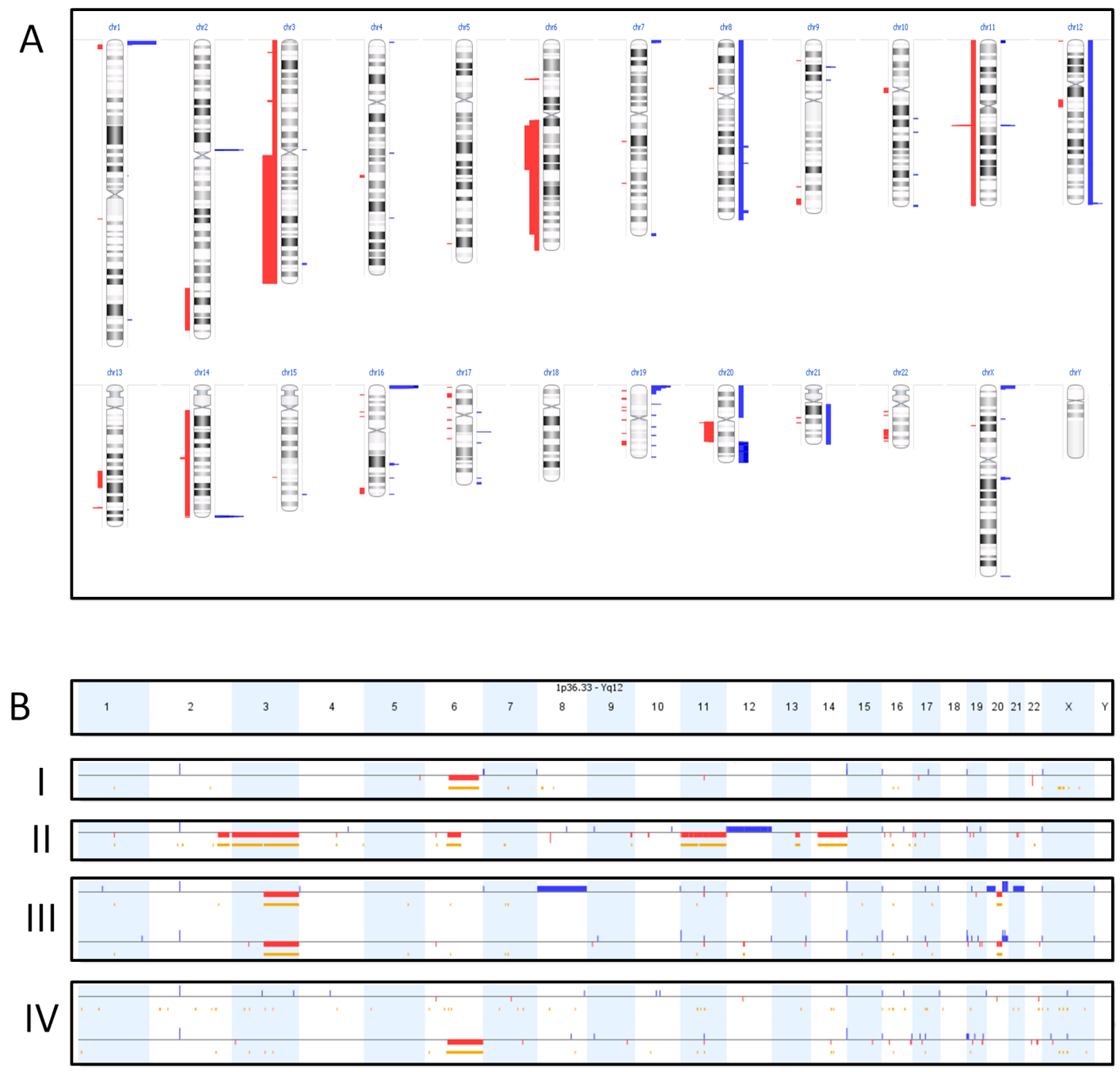

Figure 3: Oncoscan results. Figure 3A shows an overview of the number of copy-number-variations in 6 synovial sarcomas with aggregated gains (blue) and losses (red) of the different cases. The width of the bars indicates the number of cases with the gain or loss. Figure $3 \mathrm{~B}$ shows the copy number variations per sample (one per row). Gains and losses of the different chromosomes are represented by respectively blue and red lines, under the different chromosomes (depicted in columns). The length of these lines indicates the size of the gain or loss. The yellow/orange lines indicate loss of heterozygosity. BI and BII are two individual lesions showing a partial loss of chromosome 6q. BIII is a primary lesion (top line) with its corresponding metastasis (bottom line), showing a partial overlap of chromosomal aberrations but also differences. BIV are two metastases from the same patient. It shows a new deletion of chromosome $6 \mathrm{q}$ in the progressive metastasis under pazopanib treatment (bottom) compared to the metastasis responding to pazopanib (top). 


\section{DISCUSSION}

Synovial sarcoma is a rare sarcoma subtype, which is characterized by a recurring $\mathrm{X} ; 18$ translocation. Tumors show a heterogeneous clinical behavior. An in-depth genetic characterization may lead to an explanation of the clinical differences in tumor behavior and, ultimately, the identification of new therapeutic targets.

Using a next generation sequencing platform, we detected pathogenic mutations that have so far not been reported in synovial sarcoma. In contrast to earlier reports, all mutations were unique in nature, and no recurrent mutations were found. Also, no mutations were found in previously reported mutated genes in SS (Table 1).

Although each mutated gene may be involved in tumorigenesis, only two mutations that we identified in the KRAS and CCDN1 genes are presently known to be functionally important for driving cancer. Cyclin D1, encoded by the $C C N D 1$ gene, is a cell cycle regulator. It can associate with the cyclin-dependent kinases (CDKs) CDK4 and CDK6 to phosphorylate the retinoblastoma protein (RB) during the G1 phase of the cell cycle. Phosphorylation of cyclin D1 at threonine at codon 286 is required for its ubiquitination, nuclear export and degradation. Mutations at codon 287, by which the proline changes to threonine or serine, have been reported in endometrial carcinomas [35]. These mutations result in nuclear accumulation of the active Cyclin D1/CDK complex, which is refractory to rapid degradation via the $26 \mathrm{~S}$ proteasome. In our cohort, we identified a c. $859 \mathrm{C}>$ G (p.P287A) mutation and, concomitantly, we observed a cyclin D1 accumulation by immunohistochemistry. The protein encoded by the KRAS gene is involved in recruiting and activating proteins necessary for the propagation of growth factor and other receptor signaling, such as c-RAF and PI3-kinase. The single nucleotide substitution c.34C > A that we found represents an activating mutation known to result in oncogenesis in several adenocarcinomas. Non small cell lung cancer cell lines with this mutant had activated phosphatidylinositol 3-kinase (PI3K) and mitogen-activated protein/extracellular signal-regulated kinase kinase (MEK) signaling [36]. Both mutations are involved in different pathways known to be activated in SS, i.e. the WNT - $\beta$-catenin pathway which targets CCND1[37], and KRAS targeting the PI3K pathway [38]. The effect of the other mutations is not clear and therefore they could be passenger-mutations. As all eight mutations are found in genes involved in different pathways, including regulation of EGFR degradation (SEPT9) [39] or the EGFR-pathway (ERBB4) [40], angiogenesis (KDR [41], RNF213 [42]), proliferation (CSMD3 [43]) and mismatch repair (MLH1 [34]) pathways, no uniform suitable therapeutic target has emerged. The 5 -year overall survival was significantly worse in patients whose tumor harbored an additional mutation, which should be further investigated in a larger cohort. Mutations were more often found in adult tumors compared to tumors with an onset in patient younger than 18 years (Table 2).

Besides mutations, structural chromosomal aberrations have also been reported in SS. In our cohort, approximately half of the samples showed chromosomal aberrations. Some tumors had multiple alterations whereas others showed only a few or none. Also both large, including whole chromosomes, and small alterations were found. Similarly as Lagarde et al. reported, we found more stable genomes in children compared to adults [33]. Probably due to our small cohort this was not significant in our study. It is unknown if the amount of chromosomal aberrations is related to the aggressiveness of the tumor or a cause of the aggressive behavior, as genomic instability itself is related to aging and related to cancer [44]. Also, Chakiba et al. evaluated a possible association between genomic instability and response to chemotherapy, but no relation was found [45]. The deletion of $6 \mathrm{q}$ that we found may be an exception that typically raises interest in resistance mechanisms to pazopanib. As the working mechanism of pazopanib in sarcomas is still not unraveled, resistance may occur in various pathways, including antiangiogenic pathways. Partial 6q loss has been reported before in SS [29-31, 46], but so far no clinical correlation was found between 6q loss (or any other chromosomal aberration) and the clinical behavior of SS.

Our study underlines the diversity in SS genomes beyond the well-known X;18 translocation. It emphasizes the challenge in finding new druggable targets in this disease and encourages a personalized medicine approach because of the overlapping mutations with other cancer types. As was shown by the sets of primary tumor and metastases, tumor evolution is unlikely to be explained by additional mutations although our sample size was small, but change in chromosomal alterations can be found. This study also warrants further investigation of a putative correlation between chromosomal aberrations (i.e. deletion of 6q) and resistance to pazopanib. From this study we conclude that not only mutations or copy number changes may underlie the immense complexity of human cancers, including SS, and, based on our and previous results, also further epigenetic research might be a way to explore the genetic nature of SS.

\section{MATERIALS AND METHODS}

\section{Patients and tissue samples}

Tumor samples were obtained from the archives of the Department of Pathology at the Radboud University Medical Center, Nijmegen (1990-2013). In total, 36 frozen and 5 formalin-fixed, paraffin embedded (FFPE) tumor tissue samples, representing 37 patients, were included. In all patients the specific $\mathrm{t}(\mathrm{X} ; 18)$ translocation was identified 
by reverse transcriptase polymerase chain reaction (RTPCR). Patient follow-up was retrieved from clinical records. All research was performed in consultation and agreement with the medical ethical committee.

\section{Mutation analysis}

Genomic DNA was extracted by incubating the frozen/FFPE tissue samples in 5\% Chelex-100 in lysis buffer and proteinase K twice overnight. All samples were examined by a pathologist to evaluate the neoplastic cell load: all tumor cases contained more than $70 \%$ neoplastic cells. The control samples did not contain neoplastic cells. Extracted DNA samples were quantified using the Qubit (Invitrogen) and quality was checked by size ladder PCR before library preparation. Libraries were generated using Life Technologies Ion AmpliSeq ${ }^{\mathrm{TM}}$ Comprehensive Cancer Panel according to the manufacturer's recommendations. This panel consists of approximately $16 \quad 000$ primer pairs covering 409 genes with known cancer associations. 10ng of genomic DNA from each sample was used to prepare barcoded libraries using IonXpress barcoded adapters (Life Technologies). Libraries were combined to a final concentration of $3 \mathrm{ng} / \mathrm{ml}$ using the Ion Library Quantification Kit (Life Technologies, USA), and emulsion PCR was performed using the Ion Torrent OneTouchTM 2 System. Samples were sequenced on the Ion Torrent semi-conductor sequencer (Life Technologies, USA) using Ion 316 or 318 chips. Sequencing reads were aligned to the 409 genes based on the Human Genome version 19 using Sequence Pilot v4.2.0 (JSI medical systems $\mathrm{GmbH}$ ). Also read depth and uniformity of coverage across individual amplicons were assessed.

In data analysis the cut-off was set at mutations found in $\geq 20 \%$ of the reads. Only non-synonymous and non-sense variations in coding regions were included. Mutations were filtered for known single nucleotide polymorphisms and variations found earlier in our own research database. All mutations left after filtering were confirmed by Sanger sequencing with specifically designed primer sets (Supplemental Data 1), and if confirmed, the presence or absence of this specific mutation was verified in normal non-neoplastic tissue from the corresponding patient (extracted from FFPE normal tissue). PCR reactions were performed using the AmpliTaq Gold 360 Master Mix (Life Technologies, USA) with $1 \mu 1$ DNA and the following program: $95^{\circ} \mathrm{C}(10 \mathrm{~min}) ; 95^{\circ} \mathrm{C}$ (30 sec), $58 / 60^{\circ} \mathrm{C}(30 \mathrm{sec}), 72^{\circ} \mathrm{C}(1 \mathrm{~min}), 38$ cycles; and $72^{\circ} \mathrm{C}$ for $7 \mathrm{~min}$. PCR products were analyzed by agarose gel electrophoresis. Subsequently, samples were submitted to DNA sequencing using the BigDye Terminator reaction mix, and samples were analyzed on the 3730 Sequence Analyzer (Applied Biosystems). All validation was done in duplicate, including the DNA extraction process.

We extended our cohort with cohort $2(n=15)$ and analyzed these by Sanger-sequencing for the mutations that were identified in the first cohort. We also included all coding exons of KRAS and CCND1 (primers are listed in Supplemental Data 1).

\section{Oncoscan}

DNA was extracted from 3 FFPE and 3 frozen tissues and purified with ethanol precipitation to a concentration of $12 \mathrm{ng} / \mathrm{ul}$. The samples were processed with the OncoScan ${ }^{\mathrm{TM}}$ FFPE Assay, a whole-genome copy number assay, according to the manufacturers' protocol of the OncoScan ${ }^{\text {tm }}$ FFPE Assay Kit Protocol by Affymetrix. The data was analyzed with Nexus Copy Number 7.5.2, standard edition, BioDiscovery, Inc. 2014.

\section{Immunohistochemistry}

$4 \mu \mathrm{m}$ sections of FFPE tissue were pretreated in a PreTreatment module (Lab Vision) in either sodium citrate buffer (pH6.7) for $30 \mathrm{~min}$ at $100^{\circ} \mathrm{C}$ (CCND1) or in ethylenediaminetetraacetic acid (EDTA) buffer (pH9) for $10 \mathrm{~min}$ at $96^{\circ} \mathrm{C}(\mathrm{MLH} 1, \mathrm{MSH} 2, \mathrm{MSH} 6, \mathrm{PMS} 2)$. After blocking of endogenous peroxidase with $3 \%$ hydrogen peroxide in methanol, sections were incubated for $1 \mathrm{~h}$ at room temperature (RT) with the primary antibody against Cyclin D1 (ILM 30442, clone SP4; 1:40 dilution; Immunologic), MLH1 (551092, clone G168-15; 1:40 dilution; BD Pharmingen), MSH2 (NA26, clone GB12; 1:40 dilution; Calbiochem), MSH6 (ab92471, clone EPR3945; 1:500 dilution; Abcam) or PMS2 (556415, clone A16-4; 1:100 dilution; BD Pharmingen). Next, sections were incubated with PowerVision poly-HRPanti-Ms/Rb/Rt (Immunologic) for $30 \mathrm{~min}$ at RT and visualized using bright 3,3'-diaminobenzidine (DAB). Counterstaining was performed with haematoxylin. Immunostaining was evaluated by a pathologist.

\section{ACKNOWLEDGMENTS}

We thank Maartje van der Vorst, Department of Human Genetics, Radboud UMC, for her help with the data analysis.

\section{FUNDING}

This work was funded by the Synovial Sarcoma Research Foundation.

\section{CONFLICTS OF INTEREST}

The authors declare no conflict of interest. 


\section{REFERENCES}

1. Sultan I, Rodriguez-Galindo C, Saab R, Yasir S, Casanova $\mathrm{M}$ and Ferrari A. Comparing Children and Adults With Synovial Sarcoma in the Surveillance, Epidemiology, and End Results Program, 1983 to 2005 An Analysis of 1268 Patients. Cancer. 2009; 115:3537-3547.

2. Krieg AH, Hefti F, Speth BM, Jundt G, Guillou L, Exner UG, von Hochstetter AR, Cserhati MD, Fuchs B, Mouhsine E, Kaelin A, Klenke FM and Siebenrock KA. Synovial sarcomas usually metastasize after $>5$ years: a multicenter retrospective analysis with minimum follow-up of 10 years for survivors. Annals of oncology : official journal of the European Society for Medical Oncology / ESMO. 2011; 22:458-467.

3. van der Graaf WT, Blay JY, Chawla SP, Kim DW, BuiNguyen B, Casali PG, Schoffski P, Aglietta M, Staddon AP, Beppu Y, Le Cesne A, Gelderblom H, Judson IR, et al. Pazopanib for metastatic soft-tissue sarcoma (PALETTE): a randomised, double-blind, placebo-controlled phase 3 trial. Lancet. 2012; 379:1879-1886.

4. Lee SY, Haq F, Kim D, Jun C, Jo HJ, Ahn SM and Lee WS. Comparative genomic analysis of primary and synchronous metastatic colorectal cancers. PloS one. 2014; 9:e90459.

5. Tol J, Koopman M, Cats A, Rodenburg CJ, Creemers GJ, Schrama JG, Erdkamp FL, Vos AH, van Groeningen CJ, Sinnige HA, Richel DJ, Voest EE, Dijkstra JR, et al. Chemotherapy, bevacizumab, and cetuximab in metastatic colorectal cancer. The New England journal of medicine. 2009; 360:563-572.

6. Fletcher CDM BJ, Hogendoorn P, Mertens F. (2013). WHO Classification of Tumours of Soft Tissue and Bone. Fourth Edition.

7. Pilotti S, Della Torre G, Lavarino C, Di Palma S, Sozzi G, Minoletti F, Rao S, Pasquini G, Azzarelli A, Rilke F and Pierotti MA. Distinct mdm2/p53 expression patterns in liposarcoma subgroups: implications for different pathogenetic mechanisms. J Pathol. 1997; 181:14-24.

8. Crozat A, Aman P, Mandahl N and Ron D. Fusion of CHOP to a novel RNA-binding protein in human myxoid liposarcoma. Nature. 1993; 363:640-644.

9. Hirota S, Isozaki K, Moriyama Y, Hashimoto K, Nishida T, Ishiguro S, Kawano K, Hanada M, Kurata A, Takeda M, Muhammad Tunio G, Matsuzawa Y, Kanakura Y, et al. Gain-of-function mutations of c-kit in human gastrointestinal stromal tumors. Science. 1998; 279:577580.

10. Verweij J, Casali PG, Zalcberg J, LeCesne A, Reichardt P, Blay JY, Issels R, van Oosterom A, Hogendoorn PC, Van Glabbeke M, Bertulli R and Judson I. Progression-free survival in gastrointestinal stromal tumours with high-dose imatinib: randomised trial. Lancet. 2004; 364:1127-1134.

11. Clark J, Rocques PJ, Crew AJ, Gill S, Shipley J, Chan AM, Gusterson BA and Cooper CS. Identification of novel genes, SYT and SSX, involved in the $\mathrm{t}(\mathrm{X} ; 18)(\mathrm{p} 11.2 ; \mathrm{q} 11.2)$ translocation found in human synovial sarcoma. Nat Genet. 1994; 7:502-508.

12. de Leeuw B, Balemans M, Olde Weghuis D and Geurts van Kessel A. Identification of two alternative fusion genes, SYT-SSX1 and SYT-SSX2, in $\mathrm{t}(\mathrm{X} ; 18)(\mathrm{p} 11.2 ; \mathrm{q} 11.2)-$ positive synovial sarcomas. Human molecular genetics. 1995; 4:1097-1099.

13. de Bruijn DR, Allander SV, van Dijk AH, Willemse MP, Thijssen J, van Groningen JJ, Meltzer PS and van Kessel AG. The synovial-sarcoma-associated SS18-SSX2 fusion protein induces epigenetic gene (de)regulation. Cancer research. 2006; 66:9474-9482.

14. Kadoch $\mathrm{C}$ and Crabtree GR. Reversible disruption of $\mathrm{mSWI} / \mathrm{SNF}$ (BAF) complexes by the SS18-SSX oncogenic fusion in synovial sarcoma. Cell. 2013; 153:71-85.

15. Carmody Soni EE, Schlottman S, Erkizan HV, Uren A and Toretsky JA. Loss of SS18-SSX1 inhibits viability and induces apoptosis in synovial sarcoma. Clinical orthopaedics and related research. 2014; 472:874-882.

16. Takenaka S, Naka N, Araki N, Hashimoto N, Ueda T, Yoshioka K, Yoshikawa H and Itoh K. Downregulation of SS18-SSX1 expression in synovial sarcoma by small interfering RNA enhances the focal adhesion pathway and inhibits anchorage-independent growth in vitro and tumor growth in vivo. International journal of oncology. 2010; 36:823-831.

17. Haldar M, Hancock JD, Coffin CM, Lessnick SL and Capecchi MR. A conditional mouse model of synovial sarcoma: insights into a myogenic origin. Cancer cell. 2007; 11:375-388.

18. Nielsen TO, Poulin NM and Ladanyi M. Synovial sarcoma: recent discoveries as a roadmap to new avenues for therapy. Cancer discovery. 2015; 5:124-134.

19. Kawaguchi S, Tsukahara T, Ida K, Kimura S, Murase M, Kano M, Emori M, Nagoya S, Kaya M, Torigoe T, Ueda E, Takahashi A, Ishii T, et al. SYT-SSX breakpoint peptide vaccines in patients with synovial sarcoma: a study from the Japanese Musculoskeletal Oncology Group. Cancer Sci. 2012; 103:1625-1630.

20. Bloom JE, McNeel DG and Olson BM. Vaccination using peptides spanning the SYT-SSX tumor-specific translocation. Expert Rev Vaccines. 2012; 11:1401-1404.

21. Ladanyi M, Antonescu CR, Leung DH, Woodruff JM, Kawai A, Healey JH, Brennan MF, Bridge JA, Neff JR, Barr FG, Goldsmith JD, Brooks JS, Goldblum JR, et al. Impact of SYT-SSX fusion type on the clinical behavior of synovial sarcoma: a multi-institutional retrospective study of 243 patients. Cancer research. 2002; 62:135-140.

22. Guillou L, Benhattar J, Bonichon F, Gallagher G, Terrier P, Stauffer E, Somerhausen Nde S, Michels JJ, Jundt G, Vince DR, Taylor S, Genevay M, Collin F, et al. Histologic grade, but not SYT-SSX fusion type, is an important prognostic factor in patients with synovial sarcoma: a multicenter, 
retrospective analysis. Journal of clinical oncology : official journal of the American Society of Clinical Oncology. 2004; 22:4040-4050.

23. Hartley AL, Birch JM and Blair V. Malignant disease in the mothers of a population-based series of young adults with bone and soft tissue sarcomas. British journal of cancer. 1991; 63:416-419.

24. Teng HW, Wang HW, Chen WM, Chao TC, Hsieh YY, Hsih CH, Tzeng CH, Chen PC and Yen CC. Prevalence and prognostic influence of genomic changes of EGFR pathway markers in synovial sarcoma. J Surg Oncol. 2011; 103:773781.

25. Je EM, An CH, Yoo NJ and Lee SH. Mutational analysis of PIK3CA, JAK2, BRAF, FOXL2, IDH1, AKT1 and EZH2 oncogenes in sarcomas. APMIS. 2012; 120:635-639.

26. Tsuda M, Watanabe $T$, Seki $T$, Kimura $T$, Sawa $H$, Minami A, Akagi T, Isobe K, Nagashima K and Tanaka S. Induction of $\mathrm{p} 21$ (WAF1/CIP1) by human synovial sarcomaassociated chimeric oncoprotein SYT-SSX1. Oncogene. $2005 ; 24: 7984-7990$.

27. Lopez-Guerrero JA, Navarro S, Noguera R, Carda C, Farinas SC, Pellin A and Llombart-Bosch A. Mutational analysis of the c-KIT AND PDGFRalpha in a series of molecularly well-characterized synovial sarcomas. Diagn Mol Pathol. 2005; 14:134-139.

28. Joseph CG, Hwang H, Jiao Y, Wood LD, Kinde I, Wu J, Mandahl N, Luo J, Hruban RH, Diaz LA, Jr., He TC, Vogelstein B, Kinzler KW, et al. Exomic analysis of myxoid liposarcomas, synovial sarcomas, and osteosarcomas. Genes, chromosomes \& cancer. 2014; 53:15-24.

29. Szymanska J, Serra M, Skytting B, Larsson O, Virolainen M, Akerman M, Tarkkanen M, Huuhtanen R, Picci P, Bacchini P, Asko-Seljavaara S, Elomaa I and Knuutila S. Genetic imbalances in 67 synovial sarcomas evaluated by comparative genomic hybridization. Genes, chromosomes \& cancer. 1998; 23:213-219.

30. Skytting BT, Szymanska J, Aalto Y, Lushnikova T, Blomqvist C, Elomaa I, Larsson O and Knuutila S. Clinical importance of genomic imbalances in synovial sarcoma evaluated by comparative genomic hybridization. Cancer genetics and cytogenetics. 1999; 115:39-46.

31. Nakagawa Y, Numoto K, Yoshida A, Kunisada T, Ohata H, Takeda K, Wai D, Poremba C and Ozaki T. Chromosomal and genetic imbalances in synovial sarcoma detected by conventional and microarray comparative genomic hybridization. Journal of cancer research and clinical oncology. 2006; 132:444-450.

32. Przybyl J, Sciot R, Wozniak A, Schoffski P, Vanspauwen V, Samson I, Siedlecki JA, Rutkowski P and Debiec-Rychter M. Metastatic potential is determined early in synovial sarcoma development and reflected by tumor molecular features. The international journal of biochemistry \& cell biology. 2014; 53:505-513.

33. Lagarde P, Przybyl J, Brulard C, Perot G, Pierron G,
Delattre O, Sciot R, Wozniak A, Schoffski P, Terrier P, Neuville A, Coindre JM, Italiano A, et al. Chromosome instability accounts for reverse metastatic outcomes of pediatric and adult synovial sarcomas. Journal of clinical oncology : official journal of the American Society of Clinical Oncology. 2013; 31:608-615.

34. Hampel H, Frankel WL, Martin E, Arnold M, Khanduja K, Kuebler P, Nakagawa H, Sotamaa K, Prior TW, Westman J, Panescu J, Fix D, Lockman J, et al. Screening for the Lynch syndrome (hereditary nonpolyposis colorectal cancer). The New England journal of medicine. 2005; 352:1851-1860.

35. Moreno-Bueno G, Rodriguez-Perales S, Sanchez-Estevez C, Hardisson D, Sarrio D, Prat J, Cigudosa JC, Matias-Guiu $\mathrm{X}$ and Palacios J. Cyclin D1 gene (CCND1) mutations in endometrial cancer. Oncogene. 2003; 22:6115-6118.

36. Ihle NT, Byers LA, Kim ES, Saintigny P, Lee JJ, Blumenschein GR, Tsao A, Liu S, Larsen JE, Wang J, Diao L, Coombes KR, Chen L, et al. Effect of KRAS oncogene substitutions on protein behavior: implications for signaling and clinical outcome. Journal of the National Cancer Institute. 2012; 104:228-239.

37. Trautmann M, Sievers E, Aretz S, Kindler D, Michels S, Friedrichs N, Renner M, Kirfel J, Steiner S, Huss S, Koch A, Penzel R, Larsson O, et al. SS18-SSX fusion proteininduced Wnt/beta-catenin signaling is a therapeutic target in synovial sarcoma. Oncogene. 2014; 33:5006-5016.

38. Ho AL, Vasudeva SD, Lae M, Saito T, Barbashina V, Antonescu CR, Ladanyi M and Schwartz GK. PDGF receptor alpha is an alternative mediator of rapamycininduced Akt activation: implications for combination targeted therapy of synovial sarcoma. Cancer research. 2012; 72:4515-4525.

39. Diesenberg K, Beerbaum M, Fink U, Schmieder P and Krauss M. SEPT9 negatively regulates ubiquitin-dependent downregulation of EGFR. Journal of cell science. 2015; 128:397-407.

40. Normanno N, De Luca A, Bianco C, Strizzi L, Mancino M, Maiello MR, Carotenuto A, De Feo G, Caponigro F and Salomon DS. Epidermal growth factor receptor (EGFR) signaling in cancer. Gene. 2006; 366:2-16.

41. Antonescu CR, Yoshida A, Guo T, Chang NE, Zhang L, Agaram NP, Qin LX, Brennan MF, Singer S and Maki RG. KDR activating mutations in human angiosarcomas are sensitive to specific kinase inhibitors. Cancer research. 2009; 69:7175-7179.

42. Liu W, Morito D, Takashima S, Mineharu Y, Kobayashi H, Hitomi T, Hashikata H, Matsuura N, Yamazaki S, Toyoda A, Kikuta K, Takagi Y, Harada KH, et al. Identification of RNF213 as a susceptibility gene for moyamoya disease and its possible role in vascular development. PloS one. 2011; 6:e22542.

43. Liu P, Morrison C, Wang L, Xiong D, Vedell P, Cui P, Hua X, Ding F, Lu Y, James M, Ebben JD, Xu H, Adjei AA, et al. Identification of somatic mutations in non-small cell lung carcinomas using whole-exome sequencing. 
Carcinogenesis. 2012; 33:1270-1276.

44. Maslov AY and Vijg J. Genome instability, cancer and aging. Biochimica et biophysica acta. 2009; 1790:963-969.

45. Chakiba C, Lagarde P, Pissaloux D, Neuville A, Brulard C, Perot G, Coindre JM, Terrier P, Ranchere-Vince D, Ferrari A, Collini P, Suurmeijer AJ, Blay JY, et al. Response to chemotherapy is not related to chromosome instability in synovial sarcoma. Annals of oncology : official journal of the European Society for Medical Oncology / ESMO. 2014; 25:2267-2271.

46. Panagopoulos I, Mertens F, Isaksson M, Limon J, Gustafson P, Skytting B, Akerman M, Sciot R, Dal Cin P, Samson I, Iliszko M, Ryoe J, Debiec-Rychter M, et al. Clinical impact of molecular and cytogenetic findings in synovial sarcoma. Genes, chromosomes \& cancer. 2001; 31:362-372.

47. Toguchida J, Yamaguchi T, Ritchie B, Beauchamp RL, Dayton SH, Herrera GE, Yamamuro T, Kotoura Y, Sasaki MS, Little JB, Weichselbaum RR, Ishizaki K and Yandell DW. Mutation spectrum of the p53 gene in bone and soft tissue sarcomas. Cancer research. 1992; 52:6194-6199.

48. Oda Y, Sakamoto A, Satio T, Kawauchi S, Iwamoto Y and Tsuneyoshi M. Molecular abnormalities of p53, MDM2, and H-ras in synovial sarcoma. Mod Pathol. 2000; 13:9941004.

49. Pollock RE, Lang A, Luo J, El-Naggar AK and Yu D. Soft tissue sarcoma metastasis from clonal expansion of p53 mutated tumor cells. Oncogene. 1996; 12:2035-2039.

50. Schneider-Stock R, Onnasch D, Haeckel C, Mellin W, Franke DS and Roessner A. Prognostic significance of p53 gene mutations and p53 protein expression in synovial sarcomas. Virchows Arch. 1999; 435:407-412.

51. Koelsche C, Renner M, Hartmann W, Brandt R, Lehner B, Waldburger N, Alldinger I, Schmitt T, Egerer G, Penzel R, Wardelmann E, Schirmacher P, von Deimling A, et al. TERT promoter hotspot mutations are recurrent in myxoid liposarcomas but rare in other soft tissue sarcoma entities. J Exp Clin Cancer Res. 2014; 33:33.

52. Bode B, Frigerio S, Behnke S, Senn B, Odermatt B, Zimmermann DR and Moch H. Mutations in the tyrosine kinase domain of the EGFR gene are rare in synovial sarcoma. Mod Pathol. 2006; 19:541-547.

53. Dobashi Y, Suzuki S, Sugawara H and Ooi A. Involvement of epidermal growth factor receptor and downstream molecules in bone and soft tissue tumors. Hum Pathol. 2007; 38:914-925.

54. Saito T, Oda Y, Sugimachi K, Kawaguchi K, Tamiya S, Tanaka K, Matsuda S, Sakamoto A, Iwamoto Y and Tsuneyoshi M. E-cadherin gene mutations frequently occur in synovial sarcoma as a determinant of histological features. Am J Pathol. 2001; 159:2117-2124.

55. Saito T, Oda Y, Kawaguchi K, Sugimachi K, Yamamoto H, Tateishi N, Tanaka K, Matsuda S, Iwamoto Y, Ladanyi $\mathrm{M}$ and Tsuneyoshi M. E-cadherin mutation and Snail overexpression as alternative mechanisms of E-cadherin inactivation in synovial sarcoma. Oncogene. 2004; 23 :86298638.

56. Subramaniam MM, Calabuig-Farinas S, Pellin A and Llombart-Bosch A. Mutational analysis of E-cadherin, beta-catenin and APC genes in synovial sarcomas. Histopathology. 2010; 57:482-486.

57. Saito T, Oda Y, Sakamoto A, Tamiya S, Kinukawa N, Hayashi K, Iwamoto $\mathrm{Y}$ and Tsuneyoshi M. Prognostic value of the preserved expression of the E-cadherin and catenin families of adhesion molecules and of beta-catenin mutations in synovial sarcoma. J Pathol. 2000; 192:342350.

58. Sato H, Hasegawa T, Kanai Y, Tsutsumi Y, Osamura Y, Abe Y, Sakai H and Hirohashi S. Expression of cadherins and their undercoat proteins (alpha-, beta-, and gammacatenins and p120) and accumulation of beta-catenin with no gene mutations in synovial sarcoma. Virchows Arch. 2001; 438:23-30.

59. Saito T, Oda Y, Sakamoto A, Kawaguchi K, Tanaka K, Matsuda S, Tamiya S, Iwamoto Y and Tsuneyoshi M. APC mutations in synovial sarcoma. J Pathol. 2002; 196:445449.

60. Saito T, Oda Y, Kawaguchi K, Takahira T, Yamamoto H, Tanaka K, Matsuda S, Sakamoto A, Iwamoto Y and Tsuneyoshi M. PTEN and other tumor suppressor gene mutations as secondary genetic alterations in synovial sarcoma. Oncol Rep. 2004; 11:1011-1015.

61. Friedrichs N, Trautmann M, Endl E, Sievers E, Kindler D, Wurst P, Czerwitzki J, Steiner S, Renner M, Penzel R, Koch A, Larsson O, Tanaka S, et al. Phosphatidylinositol3'-kinase/AKT signaling is essential in synovial sarcoma. Int J Cancer. 2011; 129:1564-1575. 